\title{
Advances in the management of basal cell carcinoma
}

\section{Jesse M. Lewin* and John A. Carucci}

Address: 240 East $38^{\text {th }}$ Street, $12^{\text {th }}$ Floor, New York, NY 10016; USA

* Corresponding author: Jesse M. Lewin (Lewin.jesse@gmail.com)

Fl000Prime Reports 2015, 7:53 (doi:10.12703/P7-53)

All Fl000Prime Reports articles are distributed under the terms of the Creative Commons Attribution-Non Commercial License (http://creativecommons.org/licenses/by-nc/3.0/legalcode), which permits non-commercial use, distribution, and reproduction in any medium, provided the original work is properly cited.

The electronic version of this article is the complete one and can be found at: http://f1000.com/prime/reports/m/7/53

\begin{abstract}
Basal cell carcinoma (BCC), a malignant neoplasm derived from non-keratinizing cells that originate in the basal layer of the epidermis, is the most common cancer in humans. Several factors such as anatomic location, histologic features, primary or recurrent tumors, and patient characteristics influence the choice of treatment modality for BCC. Mohs micrographic surgery (MMS) facilitates optimal margin control and conservation of normal tissue for the management of BCC; however, other treatment modalities may also be implemented in the correct clinical scenario. Other treatment modalities that will be reviewed include simple excision, electrodesiccation and curettage, cryotherapy, topical immunotherapy and chemotherapy, photodynamic therapy, and radiation therapy. In addition, targeted molecular therapeutic options for the treatment of advanced or metastatic BCC will be discussed in this informal review based on recent literature obtained by using PubMed with relevant search terms.
\end{abstract}

\section{Introduction}

There are 2.8 million new cases of BCC diagnosed each year in the United States and 700,000 new cases annually in Europe $[1,2]$. There are more skin cancers in the population of the United States than there are all other cancers combined, and it is estimated that one in five Americans will develop skin cancer during their lifetime (over 95\% will be non-melanoma skin cancers) [3]. BCC, a malignant neoplasm derived from non-keratinizing cells that originate in the basal layer of the epidermis, is the most common cancer in humans. Recent studies have demonstrated a dramatic increase in the incidence of BCC among a younger population and particularly in women [4-7]. However, men generally have higher rates of BCC than do women (1.5 to 2:1) [8]. It has been postulated that the reason for this increase is the aging population, changes in sun exposure habits, environmental changes, migration patterns, and, to a lesser extent, increased prevalence of immunosuppressant use $[9,10]$. Of note, there has been a recent attempt to shift the classification of BCCs and squamous cell carcinomas (SCCs) from non-melanoma skin cancer to "keratinocyte carcinomas" because of their shared lineage with keratinocytes [11]. The authors currently refer to BCCs and SCCs specifically because of differences in biological behavior and management consideration.

\section{Pathogenesis}

The pathogenesis of BCC involves exposure of the skin to ultraviolet (UV) light, particularly the UV B spectrum (290 to $320 \mathrm{~nm}$ ) that induces mutations in tumor suppressor genes $[12,13]$. A latency period of 20 to 50 years has been described between the time of UV damage and the onset of the tumor. In most cases, BCCs develop on sun-exposed skin in the elderly, most commonly on the head and neck; however, the incidence of BCC has been rising in younger individuals, particularly women [14]. In addition, genetic syndromes such as basal cell nevus syndrome (BCNS), also called Gorlin syndrome and Xeroderma pigmentosum, predispose children and young adults to BCCs.

\section{Clinical features and diagnosis}

Clinically, BCCs may be recognized by their translucency, ulceration, telangiectasias, and the presence of a rolled border; however, it is important to note that 
features vary by clinical subtype, which include nodular (the most common subtype found on the head and neck), superficial, morpheaform, pigmented BCCs, and fibroepithelioma of Pinkus. The suspicious lesion is typically biopsied by a dermatologist via a shave or punch biopsy, and a pathologist confirms the diagnosis and histologic subtype with permanent sections. The shave biopsy technique is appropriate for most BCCs as the lesions are raised and involve the epidermis and papillary with or without reticular dermis, and thus deep subcutis and fat are not necessary to establish the diagnosis histologically. However, a punch biopsy may be useful for morpheaform BCCs that can be flat or atrophic and for recurrent BCCs occurring within a scar. Regardless of biopsy technique, full-thickness epidermis and dermis should be taken in order to adequately assess the BCC subtype and level of invasion.

\section{Aggressive features}

The National Comprehensive Cancer Network (NCCN) stratifies BCCs into low- and high-risk subtypes based on location, size, borders, recurrence, immunosuppression, site of prior radiation treatment, pathological subtype, and evidence of perineural involvement [15]. Generally, BCCs tend to be indolent tumors; however, when located on the ear, nose, eyelid, and lip, they are part of the " $\mathrm{H}$ " zone, where there is a demonstrably higher recurrence rate and potential to invade locally, resulting in tissue damage to vital structures [16]. Histologic subtypes ranging from lessaggressive patterns such as nodular and superficial to more-aggressive patterns such as infiltrative, micronodular, basosquamous, and sclerosing or morpheaform also subdivide BCCs. The aggressive subtypes are frequently more ill-defined clinically with less predictable radial growth patterns leading to greater subclinical extension of tumor. When viewed by traditional "bread loaf" processing of permanent sections after standard or staged excisions, these areas of tumor extension can be missed, leading to a false-negative result [17].

Although most BCCs are indolent slow-growing tumors, they may manifest aggressive behavior such as perineural invasion and metastatic disease. Perineural invasion, which is defined as the observation of malignant cells in the perineural space of nerves, has been reported (fewer than $0.2 \%$ of cases) [18-20]. When perineural invasion is detected, every effort should be made to clear the tumor, preferably by MMS, and at times adjuvant radiation therapy is employed. Patients with gross perineural invasion as indicated by neurologic symptoms may benefit from preoperative magnetic resonance imaging to assess the extent of tumor spread. Clinical manifestations of perineural disease may include brow paralysis due to involvement of the temporal branch of the facial nerve and mid-face paresthesias due to involvement of the trigeminal nerve. The estimated incidence of metastatic BCC has been reported to be between approximately $0.0028 \%$, or 28 cases per 1,000,000 BCC diagnoses, but has been cited as high as $0.5 \%$ [21]. Notably, over $80 \%$ of metastatic BCCs originate from primary BCCs of the head and neck [22]. BCCs that metastasize to either local or distant lymph nodes or distant organs are collectively known as advanced BCCs. A recent retrospective case series of patients with advanced BCCs followed at a tertiary care center from 1997 to 2011 suggested a median survival time of 7 years [23]. The treatment of advanced BCC will also be covered.

\section{Management Surgical options \\ Standard excision}

Standard excisions with a predetermined margin are useful for small primary BCCs on the trunk or extremities (less than $2 \mathrm{~cm}$ ) and without aggressive histologic features. During standard surgical excision of a $\mathrm{BCC}$, it is imperative to mark the clinical margin of the tumor (or prior biopsy site) and intended surgical margins before infiltration of anesthesia as this causes distortion of the tissue. A standard excision is performed in an outpatient setting with local anesthesia and excision with a $4 \mathrm{~mm}$ margin around the clinically apparent border of the tumor, down to subcutaneous fat. The authors advocate curettage prior to excision to delineate tumor margins as it has been shown to decrease surgical failure rate by $24 \%$ in BCC and is routinely performed by most dermatologic surgeons [24]. Standard excision is the mainstay of treatment for primary BCCs with non-aggressive histology (nodular or superficial), occurring on low-risk sites (trunk/extremities), where tissue conservation is not imperative (nondigital or genital skin). It has been demonstrated that a $4 \mathrm{~mm}$ surgical margin eradicates well-defined primary BCCs of less than $2 \mathrm{~cm}$ in $95 \%$ of cases [25]. However, facial nodular BCCs of less than $1 \mathrm{~cm}$ in diameter removed via standard excision with $1-, 2-$, and $3 \mathrm{~mm}$ margins lead to positive margins in $16 \%, 24 \%$, and $13 \%$ of tumors, respectively [26]. The temptation to conserve tissue on the face while removing BCCs may lead surgeons to employ inadequate margins, resulting in margin positivity during standard excision. It has also been reported that with standard excision the pathologically reported incomplete excision rate was over $10 \%$ and was significantly associated with the location on the face, particularly on the nose and inner canthus, and with infiltrative and multifocal histologic types [27]. When BCCs on the face are incompletely excised, these tumors recur between $12 \%$ and $41 \%$ of the time [28], and studies demonstrate greater efficacy of recurrent tumor clearance by using MMS versus standard re-excision $[29,30]$. 
Mohs micrographic surgery

In the 1930s, Frederic E. Mohs, a general surgeon, developed a technique of excisional surgery in which a complete margin of skin cancer was plotted in three dimensions [31]. The procedure was initially termed "chemosurgery" because it involved chemical fixation in situ before excision using zinc chloride as a fixative, combined with a permeant, and an agglutinant, which were applied to tissue in vivo while maintaining cytological detail for microscopic evaluation [32]. After this process, the tumor, along with a narrow margin of healthy tissue, was excised, and frozen sections were generated with the deep and peripheral margins in a single horizontal plane, allowing the tumor to be precisely mapped microscopically. The process has been modified with the replacement of zinc chloride fixation with local anesthesia and frozen section processing, which expedited the procedure while maintaining high cure rates.

MMS facilitates optimal margin control and conservation of normal tissue in the management of non-melanoma skin cancer [33-35]. Mohs surgeons generally perform MMS in an office setting by using local anesthesia for selected BCCs. At times, if a particular tumor requires an interdisciplinary approach (for example, an aggressive tumor infiltrating vital structures in the orbit or involving the parotid gland or facial nerve), MMS may be performed in the operating room under general anesthesia in conjunction with other surgical subspecialists such as otolaryngologists, surgical oncologists, or ophthalmologists. To perform MMS and reconstruction, the surgeon must ensure that he or she has well-trained assistants and a lab equipped for processing and reading the fresh frozen sections. The tumor is initially identified on the basis of a prior biopsy site and preferably photographs and triangulation from the physician who initially performed the definitive biopsy. The site is marked and infiltrated with local anesthesia. The tumor is debulked by using a curette, which further delineates macroscopically normal from malignant tissue by the surgeon's tactile sensation during curettage. Next, the specimen is excised tangentially, with a 45 degree angle initially. This beveled edge is in direct contrast to the 90 degree edge used during a standard excision. The beveled edge is crucial for processing leading to evaluation of the entire surgical margin after the specimen is mapped and frozen sections are prepared.

Optimal margin control is obtained by examination of the entire peripheral margin of the specimen and contiguous deep margin. Meticulous mapping allows the surgeon to remove any residual tumor in directed fashion. A defining feature of MMS is that the surgeon excises, maps, and reviews the specimen personally, minimizing the chance of error in tissue interpretation and orientation. If the Mohs surgeon, also acting as the pathologist, notes malignant cells on the margins of a section, it is marked and an additional stage is taken from the area of positivity. The process is repeated until the tumor margins are free. Next, the defect is allowed to heal by secondary intention or repaired with a linear closure, flap, or graft, depending on the size of the defect, anatomic location, and patient preference and comorbidities. Notably, there is continued investigation into using multimodal spectral imaging and Raman microspectroscopy as an alternative to traditional frozen section processing and staining during MMS; however, this technology has not yet been implemented in the clinical arena and is beyond the scope of this review [36].

MMS is the treatment of choice for recurrent BCCs as well as primary BCCs located on anatomic sites requiring maximal tissue conservation for preservation of function and cosmesis. It has been demonstrated that MMS has a 99\% cure rate for primary BCCs, compared with 91.3\% for other methods [37]. In terms of recurrent BCCs, after treatment with MMS, a second recurrence will occur at a rate of $5.6 \%$, as opposed to $17.6 \%$ for standard excision, $9.8 \%$ after radiation therapy, and $40 \%$ after curettage and desiccation [38]. This is particularly relevant to dermatologic and head-and-neck surgeons approaching facial cutaneous BCCs where the desire to avoid disfigurement and functional impairment is crucial and can lead to inadvertently performing inadequate standard excisions. MMS allows the surgeon to be flexible in the setting of positive margins and tailor the reconstruction in real time rather than having to bring the patient back for a second procedure if positive margins are identified by permanent section. One large prospective cohort study also found that MMS was an independent factor for higher long-term patient satisfaction, when compared with standard excision or electrodesiccation and curettage (EDC). Notably, in 2012, an ad hoc task force composed of members of the American Academy of Dermatology, the American College of Mohs Surgery, the American Society for Dermatologic Surgery, and the American Society for Mohs Surgery developed appropriate use criteria aimed at developing clinical guidelines for MMS indications [39]. A consensus for 270 scenarios for which MMS is frequently considered on the basis of tumor and patient characteristics was reached and the authors use them to guide their clinical practice. A mobile application has been developed and can be downloaded at [40].

\section{Destructive modalities}

\section{Electrodesiccation and curettage}

EDC is frequently used by dermatologists to treat BCCs with variable cure rates reported because of the high level of operator dependence. The procedure involves 
anesthetizing the lesional and perilesional skin, followed by curettage and electrodesiccation applied in two to three repetitions to the lesion with highest cure rates noted when a substantial peripheral margin around the initial curettage, ranging from 2 to $8 \mathrm{~mm}$, is employed. High 5-year cure rates (of up to $98.8 \%$ ) have been obtained after EDC of primary, non-fibrosing BCCs of medium- and high-risk areas of the face when performed by a skilled operator [41]. However, one study demonstrated that cure rate decreased as a function of primary lesion size: for lesions smaller than $1.0 \mathrm{~cm}$, the cure rate was $98.8 \%$; for lesions between 1.0 and $2.0 \mathrm{~cm}, 95.5 \%$; and for lesions larger than $2.0 \mathrm{~cm}, 84 \%$ [42]. In terminal hair-bearing sites, extension of neoplastic cells down follicular structures could also lead to incomplete removal or an increased risk of recurrence [43]. Cosmetic outcome following EDC on the trunk and extremities generally results in flat white macules or patches but can lead to atrophic, hypertrophic, or keloidal scars. In the authors' experience, surgical excision often leads to a better cosmetic outcome on the face compared with EDC. For appropriately selected lesions and locations, EDC remains an efficacious and cost-effective treatment modality for BCC [44].

\section{Cryosurgery}

BCC can also be treated with cryosurgery (liquid nitrogen, $-196^{\circ} \mathrm{C}$ ) by using the basic principle that freezing cycles with subzero temperatures result in sloughing of the damaged tissue and subsequent healing. The subzero temperatures induced by cryosurgery cause cellular structural changes that result in cell death. At least two freeze-thaw cycles with a tissue temperature of $-50^{\circ} \mathrm{C}$ and duration of freezing of 40 to 60 seconds are required to destroy malignant lesions, including BCC. In addition, a margin of clinically normal tissue must be destroyed to eradicate subclinical extension [44]. A systematic review of recurrence rates published during a 27-year period indicated that cryosurgery treatment of primary BCC resulted in a 5-year recurrence rate ranging from $4 \%$ to $17 \%$ [45]. It is important to note that with cryosurgery there is no histologic confirmation of removal and that a scar-like area may develop after treatment and obscure the clinician's ability to evaluate the site for future recurrence.

\section{Non-surgical options \\ Topical therapy for basal cell carcinoma Imiquimod}

Imiquimod 5\% cream, a Toll-like receptor 7 agonist, is approved by the US Food and Drug Administration (FDA) for the treatment of biopsy-confirmed, primary superficial BCCs less than $2 \mathrm{~cm}$. Imiquimod is believed to induce interferon-alpha, tumor necrosis factor-alpha, and other cytokines to boost $\mathrm{T}$ helper 1 type immunity. In clinical trials of imiquimod for superficial BCC, clinical and histologic clearance rates for dosing five and seven times per week were $75 \%$ and $73 \%$, respectively $[46,47]$. Although imiquimod is generally well tolerated, local erosion/erythema/crusting and scabbing do occur and correlate with histologic clearance rate [47]. Duration of treatment varies with local response and physician experience, and superficial BCC is generally treated with a 6-week course. In a recent trial of 202 patients with superficial BCCs who received photodynamic therapy (PDT) with methylaminolevulinate and 198 patients who received imiquimod with 12-month follow-up, the authors demonstrated the superiority of imiquimod in subgroups of females, for superficial BCC on the trunk, and for large tumors [48]. In another recent multicenter trial, 501 participants with nodular or superficial BCCs (excluding nose, temple, eyelids, and ears) were randomly assigned imiquimod daily for 6 weeks $(n=254)$ or surgical excision $(n=247)$ and followed for 3 years [49]. At year 3, 84\% of patients in the imiquimod group were treated successfully compared with $98 \%$ who underwent excisions; there was no clear difference noted between groups in patient-assessed cosmetic outcomes. Successful treatment was defined as no initial treatment failure or signs of subsequent local recurrence.

Although imiquimod can be considered for small superficial BCCs, it has not been demonstrated to be safe or efficacious for the treatment of other histologic subtypes of BCC. It should also be noted that the cost of imiquimod may exceed the costs of destructive or surgical modalities of treating BCC [50]. Imiquimod cream may be considered for patients with small superficial BCCs in low-risk anatomic locations who are unable or unwilling to undergo destructive or surgical treatments.

\section{5-Fluorouracil}

5 -Fluorouracil (5-FU), available as $2 \%$ or $5 \%$ solution or a $5 \%$ cream, is a topically applied pyrimidine analog that acts as an antimetabolite and is used in the treatment of actinic keratoses, and the 5\% cream has also been used to treat superficial BCCs. In a recent single-blind noninferiority multicenter trial of non-surgical treatments for superficial BCC, it was found that topical 5-FU (used twice daily for 4 weeks) was non-inferior, and imiquimod (used once daily 5 days per week for 6 weeks) was superior to PDT (two sessions) using methylaminolevulinate $[51,52]$. One study with no follow-up noted a $90 \%$ histologic clearance rate for superficial BCCs treated with 5-FU after 3 weeks of treatment [53]. It is important to 
note that most BCCs occurring on the head and neck are not of the superficial histologic subtype (more commonly found on the trunk) but rather are nodular and would be more appropriately treated surgically if not medically contraindicated. Notably, a recent finding from the Veterans Affairs Topical Tretinoin Chemoprevention Trial, which included 1,131 high-risk veterans who were followed for 2 to 6 years, revealed that one of the predictors of the development of a morpheaform BCC was a history of the use of fluorouracil, although fluorouracil use was not associated with an increased risk of BCC overall [54]. The authors of that trial postulated that the efficacy of fluorouracil in eliminating superficial BCCs while not fully eradicating morpheaform BCCs may be responsible for this association or that the fluorouracil may be treating cancer cells on the surface of BCCs, leaving a deeper component to proliferate.

\section{Photodynamic therapy}

PDT involves the activation of a photosensitizing drugaminolevulinic acid (ALA) or methylaminolevulinateby visible light to produce activated oxygen species that destroy the constituent cancer cells via a product of intracellular protoporphyrin IX, which preferentially accumulates in tumor cells [55]. The long-term cure rates for superficial BCC with PDT remain around 75\%, and because of the appreciable non-response and recurrence rates, patients should be monitored closely during the first 2 to 3 years after PDT, which is when most lesion recurrences are seen [56]. A recent study comparing fractionated 5-ALA PDT after partial debulking with standard surgical excision of nodular BCCs reported a $30.7 \%$ recurrence rate in the ALA-PDT group versus $2.3 \%$ in the surgically treated group with 5 -year follow-up [57]. The Cochrane Collaboration noted that cosmetic outcome for PDT was significantly better than for surgery [58]. However, there were comparatively high failure rates associated with PDT when compared with surgery, radiotherapy, and cryotherapy. Given that PDT requires a number of office visits and monitoring, it should be reserved for patients who cannot undergo surgical treatment modalities or who have multiple nonaggressive BCCs.

\section{Radiation therapy}

Radiation therapies, including external beam radiation, superficial x-ray therapy (XRT), and brachytherapy, have all been used in the treatment of BCC. Although the details of each are beyond the scope of this review, a basic understanding of these treatment modalities and their efficacy in the treatment of BCC is imperative. Superficial $\mathrm{x}$-ray differs from electron beam radiation therapy in that, in the former, light is the energy source rather than a charged particle, and the beam and delivered dose are more tightly cuffed to the intended treatment area [59]. A retrospective review of 712 BCCs (631 nodular and 81 superficial) treated with five sessions of superficial XRT demonstrated recurrence rates of $2 \%$ at 2 years and $4.2 \%$ at 5 years [60]. This may be a valuable treatment option in patients who are not surgical candidates or who refuse surgical intervention for BCC. However, radiation therapy has several disadvantages, including lack of histologic verification of tumor removal, prolonged treatment course requiring many visits, cosmetic result that may worsen over time (cutaneous atrophy and telangiectasia), and predisposition to aggressive and extensive recurrences. External beam radiation therapy can also be used as the primary treatment of low- or highrisk BCCs in patients who are not surgical candidates or as adjuvant therapy for BCC where postoperative margins are positive or for perineural involvement [44]. Another radiation modality, termed brachytherapy, involves placing the radioactive source onto or into (interstitial) the body versus external beam radiation therapy, in which the source is at a distance from the intended target tissue. Brachytherapy therefore is a more localized treatment and is most effective for small (less than $2 \mathrm{~cm}$ ), primary, or superficial (less than $2 \mathrm{~mm}$ deep) BCCs, leading to excellent functional and cosmetic results. The efficacy of interstitial brachytherapy for BCC has yet to be thoroughly studied, but one randomized control trial of 347 patients with primary facial BCCs randomly assigned to surgery or interstitial brachytherapy revealed 4-year recurrence rates of $0.7 \%$ for surgery and $7.5 \%$ in the brachytherapy group [61].

\section{Smoothened inhibitors}

Prior to the introduction of the oral smoothened inhibitor vismodegib, treatment options for advanced BCC such as surgery, radiation, and chemotherapeutics such as cisplatinbased treatment were employed but lacked evidence of efficacy because of a lack of clinical trials. It was identified that the majority of mutations in sporadic BCCs and BCCs in patients with Gorlin syndrome or BCNS occur in PTCH1, a protein that inhibits the smoothened pathway and is crucial in the hedgehog signaling pathway [62-64]. The second most common mutation in sporadic BCCs is a gain-of-function mutation of the smoothened gene, which leads to an increase in GLI1 levels, changes in transcription, and subsequent tumorigenesis [65]. In 2012, vismodegib, the only smoothened inhibitor commercially available in the United States, gained FDA approval after a phase II study with 96 advanced BCCs demonstrated an independently assessed response rate of 30\% in patients with metastatic BCC and a $43 \%$ response rate in locally advanced BCC [66]. The side effects of the smoothened inhibitors include muscle spasms, taste disturbance, alopecia, nausea, and fatigue [67]. In one study of 
vismodegib in BCNS, side effects led to discontinuation of the drug in over half of treated patients [68]. It is the authors' opinion that one crucial unanswered question is whether vismodegib will impact progression-free survival or overall survival in advanced BCC. Another valuable use for vismodegib is in patients with BCNS. A recent study of 41 BCNS patients followed for a mean of 8 months revealed a per-patient rate of new surgically eligible BCCs of 2 versus 29 per year for placebo in addition to a reduction in size of BCCs present at baseline [68].

Although there is certainly a role for targeted molecular therapy in advanced BCC and BCNS, the authors are weary of its use for so-called "unresectable" BCCs and in patients who have been classified as "non-surgical candidates". Our concern is that, with the variability in surgeon comfort and willingness to tackle challenging cases, coupled with the fear of operating on patients who are elderly and frail or have comorbid conditions, vismodegib may become overused. In addition, one must be aware of the cost of vismodegib, which is approximately $\$ 8,600$ per month, and a typical course lasts 10 months [69].

\section{Follow-up}

The NCCN recommendations for follow-up of patients with BCC include 6- to 12-month total body skin cancer screenings by a dermatologist, sun protection measures, and skin self-examinations [15]. An estimated $40 \%$ to $50 \%$ of patients with primary BCC will develop at least one BCC within 5 years and should be counseled accordingly [70].

\section{Conclusions}

The anatomic site, size of the tumor, and histologic features dictate the management of BCCs. The risk of advanced disease is low but, when present, is associated with significant morbidity and thus the authors advocate choosing an effective and appropriate initial treatment modality for BCCs to ensure eradication of the tumor. In cases of advanced BCC, a multidisciplinary approach involving surgical and medical oncology may be required, and targeted molecular therapy may be considered. In a prospective cohort study of 1,360 patients with nonmelanoma skin cancer, the authors found that most nonmelanoma skin cancers were treated surgically regardless of whether the patients were considered to have "limited life expectancy" [1]. In this study, "limited life expectancy" was defined as age of at least 85 years or patients with "multiple comorbidities". Although we feel that there is certainly value in assessing an individual patient's health status and treatment goals, we urge readers to be cautious not to withhold treatment to the point of functional compromise, which may greatly diminish quality of life in the elderly. We have provided a comprehensive and up-todate review of the various treatment modalities for BCC. Given the fortunate rarity of advanced BCC, there is a paucity of longitudinal large studies examining this population; however, we encourage more rigorous tracking and study of such cases in the future to better stratify risk and understand treatment of this subset of disease.

\section{Abbreviations}

5-FU, 5-fluorouracil; ALA, aminolevulinic acid; BCC, basal cell carcinoma; BCNS, basal cell nevus syndrome; EDC, electrodesiccation and curettage; FDA, US Food and Drug Administration; MMS, Mohs micrographic surgery; NCCN, National Comprehensive Cancer Network; PDT, photodynamic therapy; SCC, squamous cell carcinoma; UV, ultraviolet; XRT, X-ray therapy.

\section{Disclosures}

The authors declare that they have no disclosures.

\section{References}

I. Mohan SV, Chang, Anne Lynn S: Advanced Basal Cell Carcinoma: Epidemiology and Therapeutic Innovations. Curr Dermatol Rep 20|4, 3:40-5

2. Baxter JM, Patel AN, Varma S: Facial basal cell carcinoma. BMJ 20I2, 345:e5342.

3. Rigel DS, Friedman RJ, Kopf AW: Lifetime risk for development of skin cancer in the U.S. population: current estimate is now I in 5. J Am Acad Dermatol 1996, 35:1012-3.

4. Christenson LJ, Borrowman TA, Vachon CM, Tollefson MM, Otley CC, Weaver AL, Roenigk RK: Incidence of basal cell and squamous cell carcinomas in a population younger than $\mathbf{4 0}$ years. JAMA 2005, 294:68I-90.

5. Vries E de, Louwman M, Bastiaens M, Gruijl F de, Coebergh JW: Rapid and continuous increases in incidence rates of basal cell carcinoma in the southeast Netherlands since 1973. J Invest Dermatol 2004, 123:634-8.

6. Delfino $S$, Innocenzi D, Di Lorenzo G, Scalvenzi M, Montesarchio V, Feroce $F$, Baldi $A$, Persichetti $P$ : An increase in basal cell carcinoma among the young: an epidemiological study in a middle-south Italian population. Anticancer Res 2006, 26:4979-83.

7. Wu TP, Stein JA: Nonmelanoma skin cancer in young women. J Drugs Dermatol 20I3, I2:568-72.

8. Scrivener $Y$, Grosshans E, Cribier B: Variations of basal cell carcinomas according to gender, age, location and histopathological subtype. $\mathrm{Br} J$ Dermatol 2002, 147:4I-7.

9. Weinstock MA, Fisher DE: Indoor ultraviolet tanning: what the data do and do not show regarding risk of melanoma and keratinocyte malignancies. J Natl Compr Canc Netw 2010, 8:867-72; quiz 873.

10. Nan H, Kraft P, Hunter DJ, Han J: Genetic variants in pigmentation genes, pigmentary phenotypes, and risk of skin cancer in Caucasians. Int J Cancer 2009, 125:909-17.

II. Karimkhani C, Boyers LN, Dellavalle RP, Weinstock MA: It's time for 'keratinocyte carcinoma' to replace the term 'nonmelanoma skin cancer'. J Am Acad Dermatol 2015, 72:186-7.

12. Gailani MR, Leffell DJ, Ziegler A, Gross EG, Brash DE, Bale AE: Relationship between sunlight exposure and a key genetic alteration in basal cell carcinoma. J Natl Cancer Inst 1996, 88:349-54.

13. van Dam RM, Huang Z, Rimm EB, Weinstock MA, Spiegelman D, Colditz GA, Willett WC, Giovannucci E: Risk factors for basal cell 
carcinoma of the skin in men: results from the health professionals follow-up study. Am J Epidemiol 1999, I 50:459-68.

14. Situm M, Buljan M, Bulat V, Lugović Mihić L, Bolanca Z, Simić D: The role of UV radiation in the development of basal cell carcinoma. Coll Antropol 2008, 32(Suppl 2): 167-70.

15. Helveston EM, Wilson DL: A suture-reinforced scleral sling. Technique for suspension of the ptotic upper lid. Arch Ophthalmol 1975, 93:643-5.

16. Swanson NA: Otolaryngology Head \& Neck Surgery. 3rd ed. St. Louis: Mosby; 1998.

17. Salasche SJ, Amonette RA: Morpheaform basal-cell epitheliomas. A study of subclinical extensions in a series of 51 cases. J Dermatol Surg Oncol 1981, 7:387-94.

18. Niazi ZB, Lamberty BG: Perineural infiltration in basal cell carcinomas. Br J Plast Surg 1993, 46:156-7.

19. Ratner D, Lowe L, Johnson TM, Fader DJ: Perineural spread of basal cell carcinomas treated with Mohs micrographic surgery. Cancer 2000, 88: I605-I3.

20. Dunn M, Morgan MB, Beer TW: Perineural invasion: identification, significance, and a standardized definition. Dermatol Surg 2009, 35:2|4-2I.

21. Ozgediz D, Smith EB, Zheng J, Otero J, Tabatabai ZL, Corvera CU: Basal cell carcinoma does metastasize. Dermatol Online J 2008, 14:5.

22. Domarus H von, Stevens PJ: Metastatic basal cell carcinoma. Report of five cases and review of 170 cases in the literature. J Am Acad Dermatol 1984, 10:1043-60.

23. Danial C, Lingala B, Balise R, Oro AE, Reddy S, Colevas A, Chang ALS: Markedly improved overall survival in 10 consecutive patients with metastatic basal cell carcinoma. $\mathrm{Br} J$ Dermatol 2013, 169:673-6.

\section{FIOOOPRIM
RECOMMENDED}

24. Chiller K, Passaro D, McCalmont T, Vin-Christian K: Efficacy of curettage before excision in clearing surgical margins of nonmelanoma skin cancer. Arch Dermatol 2000, I36:|327-32.

25. Wolf DJ, Zitelli JA: Surgical margins for basal cell carcinoma. Arch Dermatol 1987, I 23:340-4.

26. Kimyai-Asadi A, Alam M, Goldberg LH, Peterson SR, Silapunt S, Jih MH: Efficacy of narrow-margin excision of well-demarcated primary facial basal cell carcinomas. J Am Acad Dermatol 2005, 53:464-8.

\section{FIOOOPrime
RECOMMENDED}

27. Farhi D, Dupin N, Palangié A, Carlotti A, Avril M: Incomplete excision of basal cell carcinoma: rate and associated factors among 362 consecutive cases. Dermatol Surg 2007, 33:|207-|4.

\section{FlOOOPrime \\ RECOMMENDED}

28. Bieley HC, Kirsner RS, Reyes BA, Garland LD: The use of Mohs micrographic surgery for determination of residual tumor in incompletely excised basal cell carcinoma. J Am Acad Dermatol 1992, 26:754-6.

29. Leibovitch I, Huilgol SC, Selva D, Richards S, Paver R: Basal cell carcinoma treated with Mohs surgery in Australia II. Outcome at 5-year follow-up. J Am Acad Dermatol 2005, 53:452-7.

\section{FlOOOPrime \\ RECOMMENDED}

30. Mosterd K, Krekels, Gertruud AM, Nieman FH, Ostertag JU, Essers, Brigitte AB, Dirksen CD, Steijlen PM, Vermeulen A, Neumann H, Kelleners-Smeets, Nicole WJ: Surgical excision versus Mohs' micrographic surgery for primary and recurrent basalcell carcinoma of the face: a prospective randomised controlled trial with 5-years' follow-up. Lancet Oncol 2008 , 9: 1 149-56

FIOOOPYIMP
RECOMMENDED

31. Mohs FE: Chemosurgery: a microscopically uncontrolled method of cancer excision. Arch Surg 194I, 42:279-95.

32. Mohs FE: Chemosurgery, microscopically controlled surgery for skin cancer. Springfield: Thomas; 1978.

33. Lawrence CM: Mohs' micrographic surgery for basal cell carcinoma. Clin Exp Dermatol 1999, 24:130-3.

34. Bernstein PE: Mohs' 98: single-procedure Mohs surgery with immediate reconstruction. Otolaryngol Head Neck Surg 1999, 120:184-9.

35. Shriner DL, McCoy DK, Goldberg DJ, Wagner RF: Mohs micrographic surgery. J Am Acad Dermatol 1998, 39:79-97.

36. Takamori S, Kong K, Varma S, Leach I, Williams HC, Notingher I: Optimization of multimodal spectral imaging for assessment of resection margins during Mohs micrographic surgery for basal cell carcinoma. Biomed Opt Express 2015, 6:98- III.

\section{FIOOOPrime
RECOMMENDED}

37. Rowe DE, Carroll RJ, Day CL: Long-term recurrence rates in previously untreated (primary) basal cell carcinoma: implications for patient follow-up. J Dermatol Surg Oncol 1989, 15:315-28.

38. Rowe DE, Carroll RJ, Day CL: Mohs surgery is the treatment of choice for recurrent (previously treated) basal cell carcinoma. J Dermatol Surg Oncol 1989, I 5:424-31.

39. Connolly SM, Baker DR, Coldiron BM, Fazio MJ, Storrs PA, Vidimos AT, Zalla MJ, Brewer JD, Smith Begolka W, Berger TG, Bigby M, Bolognia JL, Brodland DG, Collins S, Cronin TA, Dahl MV, Grant-Kels JM, Hanke CW, Hruza GJ, James WD, Lober CW, McBurney El, Norton SA, Roenigk RK, Wheeland RG, Wisco O]: AAD/ACMS/ASDSA/ASMS 2012 appropriate use criteria for Mohs micrographic surgery: a report of the American Academy of Dermatology, American College of Mohs Surgery, American Society for Dermatologic Surgery Association, and the American Society for Mohs Surgery. J Am Acad Dermatol 2012, 67:531-50.

\section{FlOOOPrime}

\section{RECOMMENDED}

40. American Academy of Dermatology: Mohs Surgery Appropriate Use Criteria (AUC) app. [https://www.aad.org/education/ appropriate-use-criteria/mohs-auc-app].

41. Rodriguez-Vigil T, Vázquez-López F, Perez-Oliva N: Recurrence rates of primary basal cell carcinoma in facial risk areas treated with curettage and electrodesiccation. I Am Acad Dermatol 2007, 56:91-5.

\section{FIOOOPRIme
RECOMMENDED}

42. Spiller WF, Spiller RF: Treatment of basal cell epithelioma by curettage and electrodesiccation. I Am Acad Dermatol 1984, | | :808-|4.

43. Goldman G: The current status of curettage and electrodesiccation. Dermatol Clin 2002, 20:569-78, ix.

44. Ceilley RI, Del Rosso, James Q: Current modalities and new advances in the treatment of basal cell carcinoma. Int J Dermatol 2006, 45:489-98.

45. Thissen MR, Neumann MH, Schouten LJ: A systematic review of treatment modalities for primary basal cell carcinomas. Arch Dermatol I999, I35: I I77-83.

\section{FlOOOPrime}

\section{RECOMMENDED}

46. Geisse JK, Rich P, Pandya A, Gross K, Andres K, Ginkel A, Owens M: Imiquimod $5 \%$ cream for the treatment of superficial basal 
cell carcinoma: a double-blind, randomized, vehiclecontrolled study. J Am Acad Dermatol 2002, 47:390-8.

\section{FlOOOPrime}

47. Geisse J, Caro I, Lindholm J, Golitz L, Stampone P, Owens M: Imiquimod $5 \%$ cream for the treatment of superficial basal cell carcinoma: results from two phase III, randomized, vehicle-controlled studies. J Am Acad Dermatol 2004, 50:722-33.

\section{FlOOPrime}

\section{RECOMMENDED}

48. Roozeboom MH, Nelemans PJ, Mosterd K, Steijlen PM, Arits, AHMM, Kelleners-Smeets, NWJ: Photodynamic therapy vs. topical imiquimod for treatment of superficial basal cell carcinoma: a subgroup analysis within a noninferiority randomized controlled trial. Br J Dermatol 2014.

\section{FlOOOPrime} RECOMMENDED

49. Bath-Hextall F, Ozolins M, Armstrong SJ, Colver GB, Perkins W, Miller, Paul SJ, Williams HC: Surgical excision versus imiquimod $\mathbf{5 \%}$ cream for nodular and superficial basal-cell carcinoma (SINS): a multicentre, non-inferiority, randomised controlled trial. Lancet Oncol 2014, I5:96-105.

\section{FlOOOPrime}

50. Murphy ME, Brodland DG, Zitelli JA: Definitive surgical treatment of 24 skin cancers not cured by prior imiquimod therapy: a case series. Dermatol Surg 2008, 34:I258-63.

5I. Jemal A, Murray T, Ward E, Samuels A, Tiwari RC, Ghafoor A, Feuer EJ, Thun MJ: Cancer statistics, 2005. CA: a cancer journal for clinicians. 2005, 55:10-30.

52. Arits, Aimée HMM, Mosterd K, Essers BA, Spoorenberg E, Sommer A, De Rooij, Michette JM, van Pelt, Han PA, Quaedvlieg, Patricia JF, Krekels, Gertruud AM, van Neer, Pierre AFA, Rijzewijk JJ, van Geest, Adrienne J, Steijlen PM, Nelemans PJ, KellenersSmeets, Nicole WJ: Photodynamic therapy versus topical imiquimod versus topical fluorouracil for treatment of superficial basal-cell carcinoma: a single blind, non-inferiority, randomised controlled trial. Lancet Oncol 20I3, I 4:647-54.

\section{FlOOOPrime
RECOMMENDED}

53. Gross K, Kircik L, Kricorian G: 5\% 5-Fluorouracil cream for the treatment of small superficial Basal cell carcinoma: efficacy, tolerability, cosmetic outcome, and patient satisfaction. Dermatol Surg 2007, 33:433-9; discussion 440.

\section{FlOOOPrime}

\section{RECOMMENDED}

54. Xiong MY, Korgavkar K, Digiovanna J], Weinstock MA: Fluorouracil and other predictors of morpheaform basal cell carcinoma among high-risk patients: the Veterans Affairs Topical Tretinoin Chemoprevention Trial. JAMA Dermat 2014, I50:332-4.

\section{FlOOOPrime \\ RECOMMENDED}

55. Szpringer E, Lutnicki K, Marciniak A: Photodynamic therapymechanism and employment. Ann Univ Mariae Curie Sklodowska Med 2004, 59:498-502.

56. Szeimies RM, lbbotson S, Murrell DF, Rubel D, Frambach Y, Berker D de, Dummer R, Kerrouche N, Villemagne H: A clinical study comparing methyl aminolevulinate photodynamic therapy and surgery in small superficial basal cell carcinoma $(8-20 \mathrm{~mm})$, with a I 2-month follow-up. J Eur Acad Dermatol Venereol 2008, 22: I 302-I I.

\section{FlOOOPrime}

\section{RECOMMENDED}

57. Roozeboom MH, Aardoom MA, Nelemans PJ, Thissen Monique RTM, Kelleners-Smeets NW, Kuijpers DI, Mosterd K: Fractionated 5-aminolevulinic acid photodynamic therapy after partial debulking versus surgical excision for nodular basal cell carcinoma: a randomized controlled trial with at least 5-year follow-up. J Am Acad Dermatol 2013, 69:280-7.

\section{FlOOOPrime \\ RECOMMENDED}

58. Bath-Hextall FJ, Perkins W, Bong J, Williams HC: Interventions for basal cell carcinoma of the skin. Cochrane Database Syst Rev 2007: CD0034I2.

\section{FlOOOPrime}

\section{RECOMMENDED}

59. Griep C, Davelaar J, Scholten AN, Chin A, Leer JW: Electron beam therapy is not inferior to superficial $x$-ray therapy in the treatment of skin carcinoma. Int J Radiat Oncol Biol Phys 1995, 32:1347-50.

60. Cognetta AB, Howard BM, Heaton HP, Stoddard ER, Hong HG, Green WH: Superficial x-ray in the treatment of basal and squamous cell carcinomas: a viable option in select patients. J Am Acad Dermatol 2012, 67:1235-4I.

6I. Avril MF, Auperin A, Margulis A, Gerbaulet A, Duvillard P, Benhamou E, Guillaume JC, Chalon R, Petit JY, Sancho-Garnier H, Prade M, Bouzy J, Chassagne D: Basal cell carcinoma of the face: surgery or radiotherapy? Results of a randomized study. $\mathrm{Br}$ J Cancer 1997, 76:100-6.

62. Wollina U, Tchernev G: Advanced basal cell carcinoma. Wien Med Wochenschr 2013, 163:347-53.

63. Epstein EH: Basal cell carcinomas: attack of the hedgehog. Nat Rev Cancer 2008, 8:743-54.

64. Aszterbaum M, Rothman A, Johnson RL, Fisher M, Xie J, Bonifas JM, Zhang X, Scott MP, Epstein EH: Identification of mutations in the human PATCHED gene in sporadic basal cell carcinomas and in patients with the basal cell nevus syndrome. J Invest Dermatol 1998, I | 0:885-8

65. Atwood SX, Chang, Anne Lynn S, Oro AE: Hedgehog pathway inhibition and the race against tumor evolution. J Cell Biol 20I2, 199:193-7.

66. Sekulic A, Migden MR, Oro AE, Dirix L, Lewis KD, Hainsworth JD, Solomon JA, Yoo S, Arron ST, Friedlander PA, Marmur E, Rudin CM, Chang, Anne Lynn S, Low JA, Mackey HM, Yauch RL, Graham RA, Reddy JC, Hauschild A: Efficacy and safety of vismodegib in advanced basal-cell carcinoma. N Engl J Med 2012, 366:2 I7I-9.

\section{FlOOOPrime}

\section{RECOMMENDED}

67. Jimeno A, Weiss G], Miller WH, Gettinger S, Eigl Bernard JC, Chang, Anne Lynne S, Dunbar J, Devens S, Faia K, Skliris G, Kutok J, Lewis KD, Tibes R, Sharfman WH, Ross RW, Rudin CM: Phase I study of the Hedgehog pathway inhibitor IPI-926 in adult patients with solid tumors. Clin Cancer Res 2013, 19:2766-74.

68. Tang JY, Mackay-Wiggan JM, Aszterbaum M, Yauch RL, Lindgren J, Chang K, Coppola C, Chanana AM, Marji J, Bickers DR, Epstein EH: Inhibiting the hedgehog pathway in patients with the basalcell nevus syndrome. $N$ Engl J Med 2012, 366:2180-8.

\section{FlOOOPrime}

RECOMMENDED

69. Loftus P: New Drugs Treat Advanced Stages of a Common Skin Cancer. The Wall Street Journal; 20l4. [http://www.wsj.com/ articles/new-drugs-treat-advanced-stages-of-a-common-skincancer- | 4| 6869882? KEYWORDS=basal+cell+carcinoma.].

70. Madan V, Lear JT, Szeimies R: Non-melanoma skin cancer. Lancet 2010, 375:673-85.

\section{FIOOOPrime
RECOMMENDED}

7I. Linos E, Parvataneni R, Stuart SE, Boscardin WJ, Landefeld CS, Chren $M$ : Treatment of nonfatal conditions at the end of life: nonmelanoma skin cancer. JAMA Intern Med 2013, I73:1006-I2.

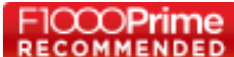

